\title{
EFFECT OF MATERNAL AGE ON POSTIMPLANTATION REPRODUCTIVE FAILURE IN MICE
}

\author{
G. B. TALBERT \\ Department of Anatomy, Downstate Medical Center, State University of New York, \\ Brooklyn, New York 11203
}

(Received 20th October 1970)

\begin{abstract}
Summary. Postimplantation reproductive failure was studied in young adult, 9-, 11-, 13- and 15-month-old C57BL/6J mice. Loss of all implanted embryos between the 8th and 18th days of pregnancy increased with advancing maternal age. The percentage of individual postimplantation deaths increased from $9 \%$ in young adults to $23 \%$ in 9-month-old mice and further increased to $45 \%$ in 11 -month-old animals. Evidence is presented that deaths most commonly occurred in the early postimplantation period.
\end{abstract}

Harman \& Talbert (1970) showed that there was a marked decline in the number of implantation sites in the uterus of $\mathrm{C} 57 \mathrm{BL} / 6 \mathrm{~J}$ mice associated with increasing maternal age. This decline began when the mice were 8 to 9 months old and continued until about 15 months of age, when implantation sites were found in only a small percentage of mice which were known to have mated.

The present investigation is an extension of this work and was designed to study the influence of maternal age on the survival of embryos and foetuses of this strain of mice between the 8th and 18th days of pregnancy.

Female mice of the G57BL/6 J strain were obtained from the Jackson Memorial Laboratory, Bar Harbor, Maine. Ageing animals were retired breeders, each of which had delivered a minimum of three litters before they were received in this laboratory. Young adult control mice were obtained from the same source and delivered one litter before inclusion in the study.

Ageing female mice and young adult controls were placed with young adult AJ-strain males late in the afternoon and were examined for the presence of a vaginal plug before 10.00 hours the following morning. Females that mated were isolated and laparotomy under Avertin anaesthesia was performed 7 days later. The number and location of implantation sites in each uterine horn were observed through a mid-ventral incision. Care was taken not to handle the implantation swellings. The incision was closed in the pregnant mice and they were killed on the 18th day of gestation. At this time, the number of foetuses and resorption sites in each horn were noted and each foetus was examined with a dissecting microscope for evidence of externally visible anomalies. The ovaries were prepared for histological study.

Animals in which no implantation sites were found at laparotomy on the 8th 
day of pregnancy were killed immediately. The ovaries and a segment of one uterine horn were saved for histological study. The size and probable functional condition of the CL in the ovaries of mice, some of which were killed on the 8th and some on the 18th day of pregnancy, were evaluated by microscopic examination.

The data in Table 1 show that there was an increase in the percentage of mice which lost all implanted embryos with advancing maternal age. This loss is significant when either the 11- or 15-month-old groups are compared with the

TABLE 1

EFFECT OF MATERNAL AGE ON LOSS OF ENTIRE LITTERS BETWEEN 8TH AND 18TH DAYS OF PREGNANGY

\begin{tabular}{c|c|c|c|c}
\hline $\begin{array}{c}\text { Age } \\
\text { (months) }\end{array}$ & $\begin{array}{c}\text { No. } \\
\text { mated }\end{array}$ & $\begin{array}{c}\text { No. pregnant } \\
\text { on 8th day }\end{array}$ & $\begin{array}{c}\text { No. pregnant } \\
\text { on 18th day }\end{array}$ & $\begin{array}{c}\text { \% Loss of } \\
\text { pregnancy }\end{array}$ \\
\hline 4 to 7 & 31 & 28 & 28 & $0 \ddagger$ \\
9 & 35 & 29 & 27 & 7 \\
11 & 35 & 28 & 22 & $21^{*}$ \\
13 & 15 & 12 & 11 & 6 \\
15 & 19 & 12 & 6 & $50 \dagger$ \\
\hline
\end{tabular}

* Significantly different from 4- to 7-month-old group, $P<0.05$ (chi-square).

+ Significantly different from 4- to 7-month-old group, $P<0.01$ (chi-square).

Significantly different from combined 11 - to 15 -month-old groups, $P<0.01$ (chisquare).

TABLE 2

EFFECT OF MATERNAL AGE ON NUMBER OF IMPLANTATION SITES AT 8 DAYS AND NUMBER OF FOETUSES AT 18 DAYS POST COITUM

\begin{tabular}{c|c|c|c|c|c}
\hline $\begin{array}{c}\text { Age } \\
\text { (months) }\end{array}$ & $\begin{array}{c}\text { No. of implants } \\
\text { at 8 days }\end{array}$ & $\begin{array}{c}\text { Implants/mating } \\
\text { at 8 days }\end{array}$ & $\begin{array}{c}\text { No. of foetuses } \\
\text { at 18 days }\end{array}$ & $\begin{array}{c}\text { Foetuses/ } \\
\text { mating }\end{array}$ & $\begin{array}{c}\text { \% Loss } \\
\mathbf{8} \text { to 18 days }\end{array}$ \\
\hline 4 to 7 & 256 & $8 \cdot 3 \pm 0.6$ & 234 & $7.5 \pm 0.6$ & $9 *$ \\
9 & 226 & $6.5 \pm 0.6$ & 173 & $4.9 \pm 0.6$ & $23 \dagger$ \\
11 & 205 & $5.9 \pm 0.6$ & 113 & $3.2 \pm 0.5$ & 45 \\
13 & 74 & $4.9 \pm 0.9$ & 42 & $2.8 \pm 0.6$ & 43 \\
15 & 57 & $3.0 \pm 0.7$ & 25 & $1.3 \pm 0.5$ & 56 \\
\hline
\end{tabular}

* Significantly lower postimplantation death rate $(P<0.01)$ than in all other age groups.

† Significantly lower postimplantation death rate $(P<0.01)$ than in all older age groups.

4- to 7-month-old group, or when all animals in the 11- to 15-month-old groups are compared with the young adult group.

There was a significant increase in the percentage of embryos which died between the 8th and 18th days of pregnancy in all ageing groups when compared with the 4- to 7-month-old control group (Table 2). There also was a significant increase in the percentage of postimplantation deaths in the 11- to 15-month-old groups when compared with the 9-month-old animals.

Externally visible congenital anomalies were found in only twelve living foetuses from mothers of all age groups. There was no evidence that the number or type of defects was influenced by maternal age. All mice which had one or 
more living foetuses on the 18th day of gestation had large CL in their ovaries which appeared to be functional although there was some vacuolation of lutein cells, particularly in the peripheral portion of these structures.

The fifteen mice which had one or more implantation sites on the 8th day of pregnancy but no living foetuses on the 18th day usually had CL in which almost all of the cells were highly vacuolated, but four of these mice still had apparently functional CL with only a moderate degree of vacuolation. In the mice which had highly vacuolated CL, there was no trace of thirty-two of the thirty-four implantation sites on the 18th day of pregnancy whereas fifteen of the eighteen implantation sites in the mice which still had apparently functional CL were present as resorbing embryos or placentae at this late stage of gestation.

It is clear from the data shown in Tables 1 and 2 that there was a steady decline with increasing maternal age in the degree of loss following implantation. This is in general agreement with the data obtained by Hollander \& Strong (1950), Sugiyama (1961) and Finn (1962). These earlier studies showed that there were more dead foetuses and resorbing embryos in old than in young adult mice of a variety of strains. However, the present study probably provides a better evaluation of postimplantation loss since an initial check of implantation sites was made on the 8th day of gestation. This method eliminated the possibility that early postimplantation deaths may have been completely resorbed or overlooked because of their small size when the uterus was examined near the end of pregnancy. Such a possibility is supported by our observation that many implantation sites which were noted on the 8th day of pregnancy were not represented by either living foetuses or resorbing embryos on the 18th day of gestation. It is clear from work in progress in this laboratory that many more resorbing embryos are present on the 14th day of gestation than were found on the 18th day, indicating that the resorption proceeds rapidly in this 4-day period. A similar pattern was observed in hamsters by Thorneycroft \& Soderwall (1969) who found fewer resorbing embryos in the uteri of senescent animals on the 14th or 15th days than were observed on the 10th or 12th days of gestation.

It was not possible to determine the exact stage of pregnancy when postimplantation losses are most likely to occur, but there appears to be good evidence that deaths are much more frequent in the early postimplantation period since conceptuses were either completely resorbed or only amorphous placental and embryonic tissues were present near term. Huggett \& Pritchard (1945) associated complete disappearance of the placenta and the embryo with death occurring before the change from a yolk-sac to a chorio-allantoic type of placenta on the 9th day of gestation in the rat. These investigators further suggested that death may often occur during this change. The common presence of only small foetal or placental remnants on the 18th day of pregnancy suggests that this stage of development may also be critical in the development of the mouse.

Complete loss of embryonic and placental tissue between the 8th and 18th days of pregnancy was clearly associated with gross degenerative changes in the corpora lutea but whether this ovarian change was the result or the cause of the loss of the conceptuses was not determined. 
The author wishes to thank Mrs Sarah Catus and Mr William Wade for their technical assistance. This work was supported by the National Institute of Ghild Health and Human Development Grant No. HD-02014.

\section{REFERENGES}

FinN, G. A. (1962) Embryonic death in aged mice. Nature, Lond. 194, 499.

Harman, S. M. \& TAlbert, G. B. (1970) The effect of maternal age on ovulation, corpora lutea of pregnancy, and implantation failure in mice. F. Reprod. Fert. $23,33$.

Hollander, W. F. \& Strong, L. G. (1950) Intra-uterine mortality and placental fusions in the mouse. F. exp. Zool. 115, 131.

Huggetr, A. ST. G. \& Pritchard, J. J. (1945) Experimental foetal death: the surviving placenta. Proc. R. Soc. Med. B, 38, 11.

Sugryama, T. (1961) Reproductive power of mother mice of different ages. Acta Sch. med. Univ. Kioto, $37,172$.

Thorneycroft, I. H. \& Soderwall, A. L. (1969) The nature of the litter size loss in senescent hamsters. Anat. Rec. 165, 343. 